\title{
Understanding The Brain-Drain From The Capital District Of New York State
}

\author{
John M. Polimeni, Albany College of Pharmacy
}

Raluca Iorgulescu, Siena College

\begin{abstract}
The Capital District Region of New York State, home to twenty-five colleges and universities with a combined 14,000 students per year is attempting to leverage this educational resource to transform its economy away from its traditional government services, industrial, and manufacturing base towards high-technology. Millions of dollars have been invested to develop the infrastructure necessary to have economic growth fueled by high-technology. However, many of these highly skilled college graduates leave the area. This exodus, or brain drain, is a major concern for regional economic developers and policy-makers because the social and economic vitality of a region is at risk. For the high-tech industry to be successful in any region there must be complementary support industries and services. Therefore, the retention of college graduates in various fields, not just those in technology disciplines, of study is vital for regional economic development. Due to the considerable threat that the brain drain poses for a region in terms of social and economic vitality, one must have a complete understanding of the problem before attempting to correct it. This study will answer the following questions: (1) How big is brain drain from the region; (2) What are the characteristics of the graduates who leave the region; (3) What are the differences between the graduates that stay in the region and those that leave; and (4) What factors can be changed to increase the probability of retaining graduates?
\end{abstract}

Keywords: Brain-drain, regional development

\section{INTRODUCTION}

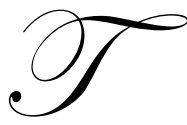

he Capital District Region of New York State (see Figure 1) ranks as the third best region in the United States for higher educational resources (Schiffman, 2003). The region has twenty-five colleges and universities which graduates approximately 14,000 students per year. The area is attempting to leverage this highly educated and skilled work-force to transform its economy away from its traditional government services, industrial, and manufacturing base towards high-technology. This initiative, known as Tech Valley, focuses largely on nanotechnology, materials science, and semiconductors by using its colleges and universities, such as Rensselaer Polytechnic Institute and the University at Albany, to increase its global technological reputation. Many millions of dollars have been invested to develop the infrastructure necessary to have economic growth fueled by high-technology. However, many young college graduates that are needed as complements to the capital investment leave the area. This exodus, or brain drain, is a major concern for regional economic developers and policy-makers because the social and economic vitality of a region is at risk.

For the high-tech industry to be successful in any region there must be complementary support industries and services. Therefore, the retention of college graduates in various fields, not just those in technology disciplines, of study is vital for regional economic development. Moreover, the loss of college graduates can create an unsustainable economic environment leading to an inefficient and less productive workforce. Other possible problems include racial, social, and economic segregation, a declining tax base for local communities, and an aging labor-force, limiting the pool of workers available to local businesses. The retention of college graduates is a hot button issue in many parts of the United States and the world because there is a clustering of both human and 
financial capital, leaving many areas behind. A skilled worker shortage poses a significant long-term threat to a region's competitive advantage.

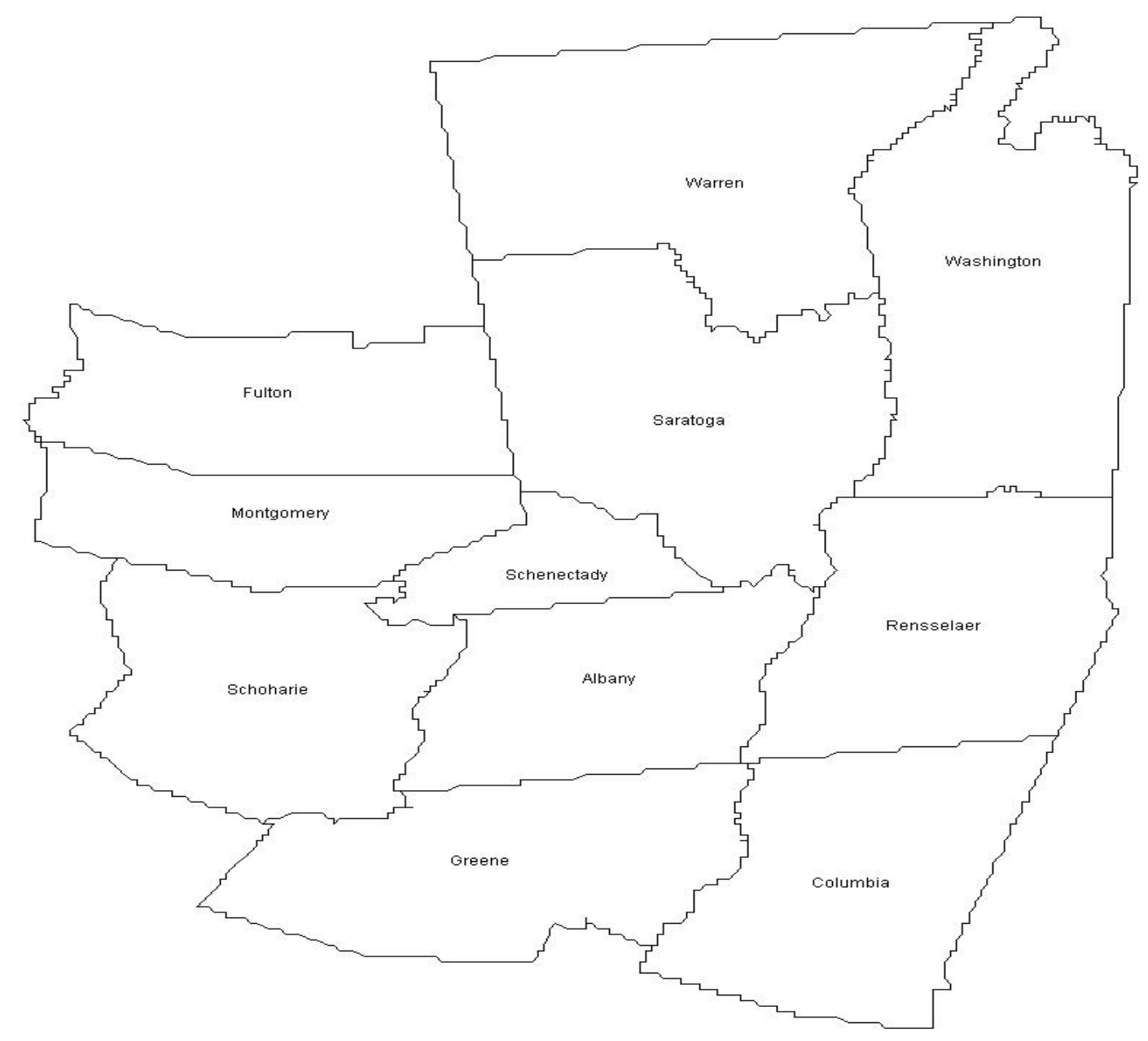

Figure 1: The Counties of New York State in the Tech Valley Initiative.

Due to the considerable threat that the brain drain poses for a region in terms of social and economic vitality, one must have a complete understanding of the problem before attempting to correct it. Despite all the media attention, there are few studies which have been conducted to examine the nature and extent to which brain drain occurs. In fact, to date, no comprehensive study of the brain drain of the Capital District has been undertaken. This study will fill that void, answering the following questions: (1) How big is brain drain from the region; (2) What are the characteristics of the graduates who leave the region; (3) What are the differences between the graduates that stay in the region and those that leave; and (4) What factors can be changed to increase the probability of retaining graduates? The following sections will outline how these questions can be addressed. Section 2 provides an in-depth analysis of the brain drain literature. Section 3 describes the data collection method. Section 4 presents the data that was collected. Finally, Section 5 concludes the paper with discussion and implications. 


\section{BRAIN DRAIN LITERATURE}

Brain drain is of particular interest to policy-makers because the migration of college graduates out of an area can have a dramatic impact on the economic development of a region. As such, there is a considerable amount of literature on the subject. Much of the literature has focused on the migration of skilled labor, particularly for developing countries.

Salt (1997) also examined the migration flows of highly skilled labor from developing and transitional countries to OECD nations. He found that highly skilled workers migrated to OECD countries at a higher rate than those migrants with lesser skills. Carrington and Detragiache (1998) confirmed the results of Salt, exploring the brain drain of developing countries by presenting estimates of emigration rates from 61 developing countries to OECD countries. They constructed an educational profile of the migrant population in the U.S. using Census information and grouped educational attainment into three categories: primary education (0-8), secondary (9-12), and tertiary (13 and above). They combined these estimates with data on educational attainment by country from an article by Barro and Lee (1993) to calculate the fraction of the population in each educational category that has migrated to the United States. Lastly, they obtained estimates of the brain drain from developing countries to OECD countries as a whole by assuming that migrants to the United States have, on average, the same educational attainment as migrants to the rest of the OECD. Carrington and Detragiache (1998) found that the majority of migrants from less developed countries have a secondary education, and those with little or no education have little access to international migration. The very well educated are the most internationally mobile group and they migrate to the United States and OECD countries.

Other research on the brain drain focused on the welfare effects of skilled labor migration. Grubel and Scott (1966) found that migrants did not impact the welfare of people who stayed in their home country. However, this study assumed perfectly competitive markets and no externalities, fairly unrealistic suppositions. In fact, Johnson (1967) found that the welfare effect is largely dependent upon the amount of capital the emigrants take with them. Bhagwati and Hamada (1974) expanded these findings using a general equilibrium framework to determine the welfare effects of skilled labor migration for those left in the home country. They introduced two distortions, one related to the wage setting and the other on financing education. They found that the integration of skilled labor on the world market impacts wages and education decisions. Skilled labor migration can raise expected wages by lowering unemployment; however, the extent of the wage changes depends on the elasticity of demand for skill labor. If wages do increase because of skilled labor migration then there could be an impact on unemployment in other sectors as well. Bhagwati and Hamada conclude that a rise in the wages of skilled labor extends unemployment to the unskilled and reduces national income, while increasing the cost of education. However, the extent of these hypotheses was unclear.

Bhagwati and Hamada (1975) built upon their previous findings by introducing various refinements to the labor markets in sending countries. For example, they used a variation of Harris-Todaro to show that emigration could be positive if the remaining skilled workers were matched to skilled jobs, thereby reducing unskilled unemployment. Although they found that emigration can reduce unemployment, this stronger labor market could reduce the flow of workers from urban to rural areas could limit any positive effects. Other studies (Rodriguez, 1975; Spence, 1974) have shown similar results.

More recent literature has expanded the research on the brain drain to propose that emigration encourages skilled labor development in the sending or home country. Mountford (1997) found that the productivity of current labor is dependent upon the share of the population that had education in the previous period. Thus, emigration has a negative direct effect by removing skilled labor from the home country, but also a beneficial effect by encouraging human capital development. In fact, empirical analyses by Beine, Docquier, and Rapaport (2001a, b) showed that some countries might experience an increase in human capital development, which influences economic growth positively, due to skilled labor migration.

However, the brain drain is not just of concern for developing countries. Several studies have been designed and conducted to examine the brain drain from Canada to the United States. Finnie (2001) used tax 
records to show that 178,000 people left Canada to migrate to the United States between 1991 and 1996. Zhao et al. (2000) built on this research finding that 49\% of those migrating to the United States between 1994 and 1999 have university degrees. Frank and Bélair (1999) reported that 12\% of doctoral degree recipients in 1995 migrated to the United States between 1995 and 1997. Furthermore, more graduates in the fields of health, engineering, and the applied sciences moved to the United States during this time period. Yet, the brain drain to the United States is considered to be the smallest level since 1851 (Murray, 2000).

Although there has been a considerable amount of research of highly educated and skilled workers migrating to the United States, there has been little research or data collection on regional brain drain within the United States, despite a considerable amount of media attention. Early work on the brain drain in the United States used national survey data. Borjas, Bronars, and Trejo (1992) analyzed the size and direction of migration flows, as well as the skill competition of migrants. They used income differentials and regional distinctions in the returns to skills from data collected in the 1979-1986 National Longitudinal Survey of Youth. Respondents to this survey were between the ages of 14 and 22 at the time of the first interview, and the subsequent annual surveys provided a detailed history of each individual's labor force activity and geographic mobility. They found that migration rates are higher for the more skilled, that an increase in skills has a larger impact on the migration propensity in states which offer relatively small payoffs to skill; high ability workers are migrating out of states with low returns to skills and low ability workers are migrating out of states with high returns to skills. Kodrzycki (2001) expanded this research, also using the National Longitudinal Survey of Youth, to present information on the geographic mobility of young adults by educational attainment and region of the country. The author found that the southern and western sections of the country gained migrants in the 1980s and 1990s from the north and east. She also found that a person's past history of migration is very important. The majority of moves were to states with stronger economies or more attractive characteristics (lower housing costs, better amenities, etc).

Regional planners, particularly those in areas with institutes of higher education, have recognized these trends and have conducted research to understand why students migrate. A 1998 study by the Pennsylvania Economy League (PEL) examined the brain drain issue for the greater Philadelphia region. This migration has concerned policy-makers because young well-educated workers are needed to supply the labor to meet the demand of local firms in the region. The PEL found that a variety of factors contribute to the brain drain, specifically quality-of-life issues and employment opportunities. Artz (2003) built upon the finding of the PEL stating that young well-educated people may migrate to find suitable entry-level jobs or for the social amenities of big cities. However, as people age their professions and lifestyles changes, and they may move again. Artz concluded that to fully understand the brain drain that the migration patterns of all college-educated workers needs to be understood, not just those in their twenties. Hansen, Ban, and Huggins (2003) further expanded the regional brain drain research by surveying recent college graduates from three Pittsburgh-area universities about their career and location decisions. They found that low salaries and lack of advancement opportunities, particularly for women, minorities, and two-career couples, were the primary reasons for migration. However, the authors found that an improving economy, low housing costs, and opportunities for continuing education were the major reasons for staying in the region.

However, the previously mentioned studies have not provided much insight on the regional migration patterns of. Therefore, several states and regions have conducted their own brain drain studies. The Wisconsin Policy Research Institute (2001) at the University of Wisconsin Oshkosh surveyed university graduates from the 1980 and 1990 classes about their family and labor market status. They found that a greater proportion of graduates from the 1980 class have left Wisconsin than has the 1990 class. Further findings indicate that the graduates that have left Wisconsin specialize in fields like science, mathematics, or medicine; fields which would have a great benefit to the Wisconsin economy. The Institute's most important finding was that graduates who left Wisconsin earn $\$ 7,000$ to $\$ 11,000$ more than graduates that remained in the state. Tornatzky et al. (2001) explored the issue deeper, conducting perhaps the largest study on the brain drain by sampling graduates from 175 colleges and universities in the southern part of the United States. The Council found that foreign students, students with majors other than engineering or the physical sciences, older students, graduates from large colleges in a metropolitan setting, or graduates from large states were more likely to stay in the state where they studied. Students who went to a research intensive university or a historically minority college, earned a degree in engineering or the physical 
sciences degrees, or graduated with a high grade point average were more likely to migrate to another state. SRI International (2002) furthered this research by examining the direct and indirect economic impacts of Michigan's public universities. They found that the direct and indirect economic impact of the fifteen public universities in Michigan was nearly $\$ 41$ billion in 1991 . Michigan appropriated $\$ 1.5$ billion to the universities, for a net impact of more than $\$ 39$ billion.

Recent works by Richard Florida, The Rise of the Creative Class (2002) and The Flight of the Creative Class (2005), have expanded the brain drain research by attempting to explain how to keep graduates from migrating. Florida argues that regional economic development is powered by creative people, and this creative class prefers regions that are diverse, tolerant, and open to new ideas. As such, he calls for policy-makers interested in economic growth in their region to promote the arts, nightlife, music, entrepreneurs, education, density, and public spaces, among other things. Detractors from Florida's ideas point out that he ignores the core functions that many people look for when migrating, such as public safety and effective schools (Steelman, 2004). In fact, Florida's ideas are not new. Schumpeter (1942) declared that the essential fact of capitalism is creative destruction. Furthermore, Adam Smith and Alfred Marshall both stated the importance of new ideas for economic growth (Steelman, 2004). Yet, despite the criticism, the popularity of Florida's thesis has spurred renewed interest in the brain drain.

There has been a considerable amount of attention to the brain drain in the Capital District because the region is making great efforts to become a global leader in materials science and nanotechnology. From 2000 to 2004 the Capital District lost 18,000 residents, a continuation of the population migration that started in the 1980s (Martialay, 2006). Much of the migration has been young college graduates and is a significant threat to the economic development of the region, as there is a lack of qualified people to fill a growing employee base. For example, in November 2007 the Capital District had an unemployment rate of 3.8\%, an increase from the $2.9 \%$ rate of September 2001, but much lower than the rate for New York State (4.4\%) or for the nation $(4.5 \%) .{ }^{1}$ This increase in the unemployment rate has resulted despite an increase in the number of jobs available since 2001. As such, there is a great interest to gain some understanding as to why college graduates may be migrating. Despite the attention, few studies have incorporated socio-economic indicators into explaining the brain drain, relying on single issues such as economic factors. The following section will describe how this study has integrated

\section{DATA COLLECTION TECHNIQUES}

To determine why graduates are leaving the Capital District, a survey of associates, bachelors, masters, and doctoral degree recipients from the 2001-2004 graduating classes from twelve colleges in the region was conducted. This study takes a different approach from other research on brain drain by including graduates from local community colleges that have not gone on to further academic degree work were included. This distinction is very important because associate's degree recipients often play a key role in high-tech expansion filling much needed support positions, whether in a direct position in the high-tech sector or in a supplier/consultant role.

Seven hundred forty-seven graduates were surveyed; only data from those graduates that are entering or entered the labor market is used. Graduates that are continuing their education will not be part of the data set as these people may have left the region strictly based on educational needs, not labor prospects. An internet survey was employed to collect the data because this method provides high-quality data and is ideal for providing statistical reliability, quick results, and a representative cross-section of the targeted population. Moreover, the respondents and their answers are anonymous.

The survey is designed to collect data on demographic, educational, employment, and other socioeconomic information. Demographic information includes variables such as race, gender, age, and marital status. Socio-economic variables include variables such as income, quality of life measures, and whether or not family

\footnotetext{
${ }^{1}$ Data obtained from the New York State Department of Labor website http://www.labor.state.ny.us/workforceindustrydata/index.asp?reg=cap
} 
members live in the Capital District. These variables serve as indicators of regional attractiveness. Information on the type of degree, the major field of study, and the grade point average was also collected.

\section{DATA ANALYSIS}

\subsection{Demographic Information}

Table 1: Demographic Information of Respondents

\begin{tabular}{|c|c|c|c|c|c|}
\hline & & \multicolumn{2}{|c|}{ Male } & \multicolumn{2}{|c|}{ Female } \\
\hline & Total $(\%)$ & Stay $(\%)$ & Migrated (\%) & Stay $(\%)$ & Migrated (\%) \\
\hline Age & 26.4 & 27.8 & 25.5 & 29.6 & 25.5 \\
\hline Single & $74.2 \%$ & $65.2 \%$ & $76.6 \%$ & $62.7 \%$ & $80.4 \%$ \\
\hline Married & $23.3 \%$ & $31.8 \%$ & $23.4 \%$ & $28.9 \%$ & $17.4 \%$ \\
\hline Divorced & $2.1 \%$ & $1.5 \%$ & $0.0 \%$ & $7.2 \%$ & $2.2 \%$ \\
\hline Widowed & $0.4 \%$ & $1.5 \%$ & $0.0 \%$ & $1.2 \%$ & $0.0 \%$ \\
\hline Caucasian & $83.7 \%$ & $95.6 \%$ & $76.5 \%$ & $95.1 \%$ & $83.1 \%$ \\
\hline African-American & $1.9 \%$ & $0.0 \%$ & $2.2 \%$ & $2.5 \%$ & $2.2 \%$ \\
\hline Asian & $9.2 \%$ & $4.4 \%$ & $15.9 \%$ & $1.2 \%$ & $9.8 \%$ \\
\hline Hispanic & $2.7 \%$ & $0.0 \%$ & $3.8 \%$ & $1.2 \%$ & $3.3 \%$ \\
\hline Other & $2.5 \%$ & $0.0 \%$ & $1.6 \%$ & $0.0 \%$ & $1.6 \%$ \\
\hline Full-time & $91.9 \%$ & $94.2 \%$ & $94.0 \%$ & $85.5 \%$ & $91.9 \%$ \\
\hline Part-time & $5.2 \%$ & $4.3 \%$ & $3.3 \%$ & $12.1 \%$ & $4.3 \%$ \\
\hline Unemployed & $2.9 \%$ & $1.5 \%$ & $2.7 \%$ & $2.4 \%$ & $3.8 \%$ \\
\hline$\$ 0-\$ 50,000$ & $59.8 \%$ & $52.2 \%$ & $44.2 \%$ & $85.4 \%$ & $66.9 \%$ \\
\hline$\$ 50,000-\$ 75,000$ & $29.4 \%$ & $29.0 \%$ & $39.8 \%$ & $10.9 \%$ & $27.6 \%$ \\
\hline$>\$ 75,000$ & $10.7 \%$ & $18.8 \%$ & $16.0 \%$ & $3.7 \%$ & $5.5 \%$ \\
\hline Avg. Household Size & 2.1 & 1.99 & 2 & 2.22 & 2.25 \\
\hline Avg. Number of Workers per Household & 1.71 & 1.51 & 1.66 & 1.7 & 1.85 \\
\hline Avg. Number of Children per Household & 0.2 & 0.3 & 0.17 & 0.43 & 0.22 \\
\hline GPA (out of 4.0) & 3.43 & 3.26 & 3.6 & 3.44 & 3.33 \\
\hline $\mathrm{n}=520$ & & & & & \\
\hline
\end{tabular}

Of the seven hundred forty-seven graduates that were surveyed, 146 were attending graduate school and eliminated from the survey, leaving 601 respondents and 520 fully completed surveys, providing a large crosssection from which to examine. Table 1 presents the demographic information of the respondents. Only $28.6 \%$ of those graduates answering the survey currently reside in the Capital District. The gender of the respondents included $48.7 \%$ male and $51.3 \%$ female. Additionally, $83.7 \%$ of the respondents are Caucasian, $9.2 \%$ are Asian, $2.7 \%$ are Hispanic, and $1.9 \%$ are African-American. Most of the respondents are employed full-time (91.9\%), while $5.2 \%$ are employed part-time, and $2.9 \%$ are unemployed. As for income levels, $59.8 \%$ of the respondents earn less than $\$ 50,000,29.4 \%$ earn $\$ 50,000$ to $\$ 75,000$, and $10.7 \%$ earn more than $\$ 75,000$. The average age of those taking the survey is 26.4 years of age. Nearly $97 \%$ of the respondents are American citizens, while $74.2 \%$ are single, $23.3 \%$ are married, and $2.5 \%$ are either divorced or widowed. The average household of respondents consists of 2.1 people, of which 1.71 work, and 0.2 are children.

Deeper comparative analysis shows a distinct difference among migrant graduates and graduates remaining in the Capital District. The gender of graduates remaining in the region is split $45.4 \%$ male and $54.6 \%$ female, while the gender of the migrants is split equally, 50\% male and 50\% female. However, there is a large divergence in 
some key demographic areas. Graduates that remain in the Capital District are overwhelming Caucasian, $95.6 \%$ of men and $95.1 \%$ of women. In fact, very few non-Caucasian graduates remain in the region. The reason for this is unclear from the results, but this finding indicates that non-Caucasians are not comfortable in the region, a result that should be of concern for stakeholders. Another area of divergence is in age. Both male (27.8 years) and female (29.6 years) graduates staying in the region are older than migrant graduates (25.5 years for males and females). This result also translates into a difference in marital status between the two groups. Only $20.4 \%$ of migrants are married as compared to $30.6 \%$ for those staying in the Capital District, indicating that single graduates are much more likely to migrate. Due to this difference in marriage status, the average number of children in the households of graduates that stayed in the region is double that of the households of graduates that left the area, 0.38 compared to 0.19 . Moreover, the average number of workers in households of the migrating graduates is greater, 1.76 as compared to 1.61 workers per household for graduates remaining in the region. A comparison of the salaries earned by the two groups also provides important information. Migrant graduates tend to earn more money than graduates remaining in the Capital District.

The final two categories will not be broken down into subcategories because the statistics for the different groups (stay, migrated, male, female) are not much different from the aggregate results. Most graduates from local colleges earned either a B.A. or B.S. (72.1\%), 11.7\% received a master's degree, 5.8\% earned a Ph.D., 7.8\% received M.D.'s, $2.5 \%$ received an associate's degree, and $0.2 \%$ earned a law degree. The overwhelming majority of the respondents graduated from a private college of university (97.1\%) in the Capital District, while the remaining $2.9 \%$ graduated from a public college or university. The average grade point average of those who responded is 3.43 out of a 4.0 scale. Many of the graduates attended a college or university that had an internship program $(75.3 \%)$ and/or a co-operative employment program (42.7\%). Only $4.5 \%$ of graduates went to an institution of higher learning that did not have any of these affiliations.

Of particular interest is that $47.2 \%$ of respondents graduated from an institution with a technology or research park affiliation. There are 243 graduates that responded that there college/university has a research or technology park affiliation. Of those respondents $74.9 \%$ migrated from the region. This result is important because technology and research parks, if available, are an important component of regional economic development because they provide interaction between a university and tenant companies that often leads to cutting edge technological developments. The university supplies the infrastructure and the tenant takes a lease at a reasonable rate. Thus, both sides benefit. The companies enhance the educational experience of the university and provide extra revenue by becoming an affiliate of the university. This in turn enables the companies to the university's resources.

\subsection{Quality-Of-Life Indicators}

Table 2: Factors that Contributed to Graduates Remaining in the Capital District

\begin{tabular}{|c|c|c|c|}
\hline & Total $(\%)$ & Male $(\%)$ & Female $(\%)$ \\
\hline Climate (Weather) & $11.2 \%$ & $10.1 \%$ & $12.0 \%$ \\
\hline Salary opportunities & $20.4 \%$ & $20.3 \%$ & $20.5 \%$ \\
\hline Cultural diversity & $2.6 \%$ & $1.4 \%$ & $3.6 \%$ \\
\hline Cost of living & $48.7 \%$ & $52.2 \%$ & $45.8 \%$ \\
\hline Crime & $7.2 \%$ & $7.2 \%$ & $7.2 \%$ \\
\hline Education (opportunities for family) & $20.4 \%$ & $21.7 \%$ & $19.3 \%$ \\
\hline Health Care & $7.9 \%$ & $10.1 \%$ & $6.0 \%$ \\
\hline Employment opportunities & $63.2 \%$ & $59.4 \%$ & $66.3 \%$ \\
\hline Recreational opportunities & $21.1 \%$ & $18.8 \%$ & $22.9 \%$ \\
\hline Opportunities to socialize & $23.0 \%$ & $21.7 \%$ & $24.1 \%$ \\
\hline Cultural opportunities & $7.2 \%$ & $7.2 \%$ & $7.2 \%$ \\
\hline Transportation & $7.9 \%$ & $7.2 \%$ & $8.4 \%$ \\
\hline Size of the region & $19.7 \%$ & $18.8 \%$ & $20.5 \%$ \\
\hline Relative closeness to other areas & $46.1 \%$ & $52.2 \%$ & $41.0 \%$ \\
\hline Family & $63.8 \%$ & $62.3 \%$ & $65.1 \%$ \\
\hline Other & $9.9 \%$ & $7.2 \%$ & $12.0 \%$ \\
\hline
\end{tabular}


Table 3: Ratings of Quality-of-life Indicators by Graduates that Remained in the Capital District

\begin{tabular}{|c|c|c|c|c|c|c|c|c|c|c|c|c|}
\hline & \multicolumn{4}{|c|}{ Total } & \multicolumn{4}{|c|}{ Male } & \multicolumn{4}{|c|}{ Female } \\
\hline & $\begin{array}{c}\text { Very } \\
\text { Good }\end{array}$ & Good & $\mathrm{Bad}$ & $\begin{array}{l}\text { Very } \\
\text { Bad }\end{array}$ & $\begin{array}{l}\text { Very } \\
\text { Good }\end{array}$ & Good & $\mathrm{Bad}$ & $\begin{array}{l}\text { Very } \\
\text { Bad }\end{array}$ & $\begin{array}{c}\text { Very } \\
\text { Good }\end{array}$ & Good & $\mathrm{Bad}$ & $\begin{array}{l}\text { Very } \\
\text { Bad }\end{array}$ \\
\hline Climate (Weather) & $3.9 \%$ & $46.1 \%$ & $27.6 \%$ & $11.8 \%$ & $4.35 \%$ & $44.93 \%$ & $36.23 \%$ & $14.49 \%$ & $3.6 \%$ & $47.0 \%$ & $20.5 \%$ & $9.6 \%$ \\
\hline Salary opportunities & $1.3 \%$ & $59.9 \%$ & $23.7 \%$ & $4.6 \%$ & $1.4 \%$ & $65.2 \%$ & $26.1 \%$ & $7.2 \%$ & $1.2 \%$ & $55.4 \%$ & $21.7 \%$ & $2.4 \%$ \\
\hline Cultural diversity & $5.3 \%$ & $59.2 \%$ & $23.7 \%$ & $1.3 \%$ & $4.3 \%$ & $68.1 \%$ & $26.1 \%$ & $1.4 \%$ & $6.0 \%$ & $51.8 \%$ & $21.7 \%$ & $1.2 \%$ \\
\hline Cost of living & $21.7 \%$ & $61.2 \%$ & $5.9 \%$ & $0.7 \%$ & $29.0 \%$ & $66.7 \%$ & $4.3 \%$ & $0.0 \%$ & $15.7 \%$ & $56.6 \%$ & $7.2 \%$ & $1.2 \%$ \\
\hline Crime & $7.2 \%$ & $60.5 \%$ & $20.4 \%$ & $1.3 \%$ & $13.0 \%$ & $68.1 \%$ & $18.8 \%$ & $0.0 \%$ & $2.4 \%$ & $54.2 \%$ & $21.7 \%$ & $2.4 \%$ \\
\hline Education (opportunities for family) & $32.2 \%$ & $55.3 \%$ & $0.7 \%$ & $1.3 \%$ & $31.9 \%$ & $63.8 \%$ & $1.4 \%$ & $2.9 \%$ & $32.5 \%$ & $48.2 \%$ & $0.0 \%$ & $0.0 \%$ \\
\hline Health Care & $15.8 \%$ & $66.4 \%$ & $5.3 \%$ & $2.0 \%$ & $14.5 \%$ & $76.8 \%$ & $7.2 \%$ & $1.4 \%$ & $16.9 \%$ & $57.8 \%$ & $3.6 \%$ & $2.4 \%$ \\
\hline Employment opportunities & $2.0 \%$ & $60.5 \%$ & $23.7 \%$ & $3.3 \%$ & $2.9 \%$ & $60.9 \%$ & $31.9 \%$ & $4.3 \%$ & $1.2 \%$ & $60.2 \%$ & $16.9 \%$ & $2.4 \%$ \\
\hline Recreational opportunities & $18.4 \%$ & $57.9 \%$ & $10.5 \%$ & $2.6 \%$ & $24.6 \%$ & $62.3 \%$ & $10.1 \%$ & $2.9 \%$ & $13.3 \%$ & $54.2 \%$ & $10.8 \%$ & $2.4 \%$ \\
\hline Opportunities to socialize & $14.5 \%$ & $55.9 \%$ & $15.1 \%$ & $3.9 \%$ & $11.6 \%$ & $65.2 \%$ & $17.4 \%$ & $5.8 \%$ & $16.9 \%$ & $48.2 \%$ & $13.3 \%$ & $2.4 \%$ \\
\hline Cultural opportunities & $8.6 \%$ & $52.0 \%$ & $25.7 \%$ & $3.3 \%$ & $10.1 \%$ & $52.2 \%$ & $33.3 \%$ & $4.3 \%$ & $7.2 \%$ & $51.8 \%$ & $19.3 \%$ & $2.4 \%$ \\
\hline Transportation & $5.9 \%$ & $56.6 \%$ & $23.0 \%$ & $3.9 \%$ & $1.4 \%$ & $63.8 \%$ & $29.0 \%$ & $5.8 \%$ & $9.6 \%$ & $50.6 \%$ & $18.1 \%$ & $2.4 \%$ \\
\hline Size of the region & $13.2 \%$ & $69.7 \%$ & $5.9 \%$ & $0.7 \%$ & $15.9 \%$ & $76.8 \%$ & $5.8 \%$ & $1.4 \%$ & $10.8 \%$ & $63.9 \%$ & $6.0 \%$ & $0.0 \%$ \\
\hline
\end{tabular}


The responses to how graduates feel about the quality-of-life in the Capital District provide additional information and substantiate the results of the socio-economic data collected. Consider the following information that was collected. Only 59.4\% of graduates that stayed in the region plan on making the Capital District their longterm home. Thus, the question as to why these people stayed in the region in the first place must be answered. Table 2 provides a list of factors that contributed to graduates remaining in the Capital District and the responses. The main reasons that people remain in the region after graduation are family $(63.8 \%)$, employment opportunities (63.2\%), the cost of living (48.7\%), and the relative closeness of the Capital District to other areas (46.1\%). Table 3 provides the ratings by graduates that stayed in the area of various quality-of-life indicators. As shown in the table, educational opportunities rate the highest, followed by the cost of living, health care, and the size of the region. The weather, transportation, cultural diversity, employment, salary, and cultural opportunities rate the lowest. While the data gathered from graduates that remained in the region provide some interesting insights, to truly understand the brain drain the information obtained from those people who migrated should be the primary focus.

Table 4 presents the results of the reasons why graduates left the region. The overwhelming majority of graduates who migrated did so for employment $(75.7 \%)$ and salary opportunities $(41.1 \%)$. Similar to respondents that stayed in the Capital District, family (30.7\%) played a vital role. Three out of the next four reasons were all related; social $(27.2 \%)$, recreational $(25 \%)$, and cultural opportunities $(21.8 \%)$. These reasons for migrating indicate the graduates, who are largely young and single, value entertainment opportunities and the ability to interact with others much more than those who stayed in the region.

Table 4: Factors that Contributed to Graduates Leaving the Capital District

\begin{tabular}{|c|c|c|c|}
\hline & Total (\%) & Male (\%) & Female $(\%)$ \\
\hline Climate (Weather) & $24.8 \%$ & $24.5 \%$ & $26.6 \%$ \\
\hline Salary opportunities & $41.1 \%$ & $42.9 \%$ & $37.5 \%$ \\
\hline Cultural diversity & $12.6 \%$ & $12.0 \%$ & $14.7 \%$ \\
\hline Cost of living & $4.0 \%$ & $3.3 \%$ & $4.9 \%$ \\
\hline Crime & $7.9 \%$ & $10.3 \%$ & $6.0 \%$ \\
\hline Education (opportunities for family) & $5.7 \%$ & $7.1 \%$ & $5.4 \%$ \\
\hline Health Care & $1.7 \%$ & $1.6 \%$ & $1.6 \%$ \\
\hline Employment opportunities & $75.7 \%$ & $76.6 \%$ & $73.9 \%$ \\
\hline Recreational opportunities & $25.0 \%$ & $27.2 \%$ & $23.9 \%$ \\
\hline Opportunities to socialize & $27.2 \%$ & $23.4 \%$ & $32.6 \%$ \\
\hline Cultural opportunities & $21.8 \%$ & $19.0 \%$ & $25.5 \%$ \\
\hline Transportation & $8.7 \%$ & $8.2 \%$ & $9.2 \%$ \\
\hline Size of the region & $11.9 \%$ & $10.9 \%$ & $13.6 \%$ \\
\hline Relative closeness to other areas & $17.1 \%$ & $13.0 \%$ & $22.3 \%$ \\
\hline Family & $30.7 \%$ & $31.0 \%$ & $33.2 \%$ \\
\hline Other & $22.0 \%$ & $21.2 \%$ & $25.0 \%$ \\
\hline
\end{tabular}

Graduates that migrated from the region were also asked to rank various quality-of-life indicators; the results are presented in Table 5. The migrant graduates ranked the cost of living as the best attribute of the region, closely followed by educational opportunities. These two factors were trailed by health care and size of the region. The weather and employment opportunities were ranked as the two worst attributes of the Capital District. 
Table 5: Ratings of Quality-of-life Indicators by Graduates that Migrated from the Capital District

\begin{tabular}{|c|c|c|c|c|c|c|c|c|c|c|c|c|}
\hline & \multicolumn{4}{|c|}{ Total } & \multicolumn{4}{|c|}{ Male } & \multicolumn{4}{|c|}{ Female } \\
\hline & $\begin{array}{c}\text { Very } \\
\text { Good }\end{array}$ & Good & $\mathrm{Bad}$ & $\begin{array}{l}\text { Very } \\
\text { Bad } \\
\end{array}$ & $\begin{array}{c}\text { Very } \\
\text { Good }\end{array}$ & Good & $\mathrm{Bad}$ & $\begin{array}{l}\text { Very } \\
\text { Bad } \\
\end{array}$ & $\begin{array}{c}\text { Very } \\
\text { Good }\end{array}$ & Good & $\mathrm{Bad}$ & $\begin{array}{l}\text { Very } \\
\text { Bad } \\
\end{array}$ \\
\hline Climate (Weather) & $4.5 \%$ & $43.8 \%$ & $36.6 \%$ & $15.1 \%$ & $5.4 \%$ & $44.0 \%$ & $32.6 \%$ & $17.9 \%$ & $2.7 \%$ & $42.4 \%$ & $40.8 \%$ & $14.1 \%$ \\
\hline Salary opportunities & $2.2 \%$ & $48.5 \%$ & $42.1 \%$ & $7.2 \%$ & $3.3 \%$ & $41.8 \%$ & $44.0 \%$ & $10.9 \%$ & $1.1 \%$ & $54.9 \%$ & $40.2 \%$ & $3.8 \%$ \\
\hline Cultural diversity & $10.6 \%$ & $54.5 \%$ & $30.7 \%$ & $4.2 \%$ & $10.3 \%$ & $52.7 \%$ & $31.5 \%$ & $5.4 \%$ & $8.7 \%$ & $57.6 \%$ & $29.9 \%$ & $3.8 \%$ \\
\hline Cost of living & $36.1 \%$ & $57.9 \%$ & $5.4 \%$ & $0.5 \%$ & $38.0 \%$ & $57.1 \%$ & $4.3 \%$ & $0.5 \%$ & $35.9 \%$ & $57.1 \%$ & $6.5 \%$ & $0.5 \%$ \\
\hline Crime & $6.2 \%$ & $50.5 \%$ & $37.1 \%$ & $6.2 \%$ & $10.3 \%$ & $48.4 \%$ & $35.9 \%$ & $5.4 \%$ & $2.2 \%$ & $51.1 \%$ & $39.1 \%$ & $7.6 \%$ \\
\hline Education (opportunities for family) & $30.7 \%$ & $59.9 \%$ & $8.4 \%$ & $1.0 \%$ & $37.0 \%$ & $52.2 \%$ & $9.2 \%$ & $1.6 \%$ & $23.9 \%$ & $67.4 \%$ & $8.2 \%$ & $0.5 \%$ \\
\hline Health Care & $10.4 \%$ & $76.7 \%$ & $12.9 \%$ & $0.0 \%$ & $11.4 \%$ & $77.2 \%$ & $11.4 \%$ & $0.0 \%$ & $8.7 \%$ & $76.1 \%$ & $15.2 \%$ & $0.0 \%$ \\
\hline Employment opportunities & $2.2 \%$ & $45.8 \%$ & $41.6 \%$ & $10.4 \%$ & $2.2 \%$ & $40.2 \%$ & $42.9 \%$ & $14.7 \%$ & $2.7 \%$ & $50.0 \%$ & $39.7 \%$ & $7.6 \%$ \\
\hline Recreational opportunities & $14.4 \%$ & $53.2 \%$ & $26.2 \%$ & $6.2 \%$ & $20.1 \%$ & $47.3 \%$ & $23.9 \%$ & $8.7 \%$ & $7.6 \%$ & $56.5 \%$ & $31.0 \%$ & $4.9 \%$ \\
\hline Opportunities to socialize & $11.1 \%$ & $52.7 \%$ & $29.5 \%$ & $6.7 \%$ & $13.6 \%$ & $51.1 \%$ & $26.1 \%$ & $9.2 \%$ & $8.7 \%$ & $50.5 \%$ & $35.3 \%$ & $5.4 \%$ \\
\hline Cultural opportunities & $6.4 \%$ & $47.8 \%$ & $39.9 \%$ & $5.9 \%$ & $7.6 \%$ & $46.2 \%$ & $39.7 \%$ & $6.5 \%$ & $4.3 \%$ & $48.9 \%$ & $40.2 \%$ & $6.5 \%$ \\
\hline Transportation & $5.0 \%$ & $50.0 \%$ & $36.1 \%$ & $8.9 \%$ & $6.5 \%$ & $49.5 \%$ & $38.0 \%$ & $6.0 \%$ & $3.8 \%$ & $48.9 \%$ & $35.9 \%$ & $11.4 \%$ \\
\hline Size of the region & $12.9 \%$ & $67.6 \%$ & $18.6 \%$ & $1.0 \%$ & $14.7 \%$ & $66.8 \%$ & $16.8 \%$ & $1.6 \%$ & $11.4 \%$ & $66.3 \%$ & $21.7 \%$ & $0.5 \%$ \\
\hline
\end{tabular}

Table 6: How Likely are Graduates that Migrated from the Capital District to Return?

\begin{tabular}{|c|c|c|c|c|c|c|c|c|c|c|c|c|c|c|}
\hline \multicolumn{5}{|c|}{ Total } & \multicolumn{5}{|c|}{ Male } & \multicolumn{5}{|c|}{ Female } \\
\hline $\begin{array}{c}\text { Very } \\
\text { Likely }\end{array}$ & Likely & Neutral & $\begin{array}{c}\text { Not } \\
\text { Likely }\end{array}$ & $\begin{array}{c}\text { Definitely } \\
\text { Not }\end{array}$ & $\begin{array}{c}\text { Very } \\
\text { Likely }\end{array}$ & Likely & Neutral & $\begin{array}{c}\text { Not } \\
\text { Likely } \\
\end{array}$ & $\begin{array}{c}\text { Definitely } \\
\text { Not }\end{array}$ & $\begin{array}{c}\text { Very } \\
\text { Likely }\end{array}$ & Likely & Neutral & $\begin{array}{c}\text { Not } \\
\text { Likely } \\
\end{array}$ & $\begin{array}{c}\text { Definitely } \\
\text { Not }\end{array}$ \\
\hline $6.4 \%$ & $12.1 \%$ & $23.3 \%$ & $41.3 \%$ & $16.8 \%$ & $8.15 \%$ & $10.33 \%$ & $26.09 \%$ & $38.04 \%$ & $17.39 \%$ & $3.3 \%$ & $13.0 \%$ & $16.8 \%$ & $49.5 \%$ & $17.4 \%$ \\
\hline
\end{tabular}


As presented in Table 6, when asked how likely they were to consider moving back to the Capital District only $18.5 \%$ of the respondents who migrated indicated that they were very likely or likely to return to the region. More than $58 \%$ of graduates stated that they were unlikely or definitely would not consider moving back to the area. When asked why they would consider returning to the Capital District, shown in Table 7, employment opportunities $(54.8 \%)$, cost of living (53\%), and family (45.8\%) ranked as the top three factors. Other factors of note are the relative closeness of the Capital District to major cities such as New York, Boston, and Philadelphia (36.9\%), educational opportunities for family (32.7\%), and salary opportunities (29.8\%). The factors that have little influence on graduates moving back to the region are health care and transportation (4.2\%). One should note that the results presented in Table 7 could not be broken-down by gender because many graduates did not state any reason(s) for returning to the Capital District. However, all of this data provides much needed insight into the repercussion of brain drain for the region.

Table 7: Why Would Graduates that Migrated Return to the Capital District?

\begin{tabular}{|l|c|}
\hline Salary opportunities & $29.8 \%$ \\
Cost of living & $53.0 \%$ \\
Crime & $5.4 \%$ \\
Education (opportunities for family) & $32.7 \%$ \\
Health Care & $4.2 \%$ \\
Employment Opportunities & $54.8 \%$ \\
Recreational opportunities & $28.0 \%$ \\
Opportunities to socialize & $20.8 \%$ \\
Cultural opportunities & $13.1 \%$ \\
Transportation & $4.2 \%$ \\
Size of the region & $28.6 \%$ \\
Relative closeness to other areas & $36.9 \%$ \\
Family & $45.8 \%$ \\
Other & $4.8 \%$ \\
\hline
\end{tabular}

\section{DISCUSSION AND IMPLICATIONS}

Similar to other regions wanting economic growth, the Capital District region of New York State must have jobs available for graduates. The unemployment statistics for the region which were reported earlier indicate that the labor market is favorable for people looking for employment. However, the main reasons for graduates to migrate, as indicated by the survey, are employment and salary opportunities. Therefore, this result leads one to conclude that the jobs that these graduates want are not available. From 2001 to 2006 the annual average employment in the professional, scientific, and technical services sector has increased by only 1,300 jobs, from 25,600 to 26,900, while management of companies and enterprises decreased from 7,200 to 6,600. ${ }^{2}$ Furthermore, the annual average employment in the information sector decreased from 12,100 to $10,700{ }^{3}$ The largest growth during this time period, in total number of jobs, came in the educational and health services sector; the health care and social assistance sector and the ambulatory health care services sector. The employment statistics for the Capital District indicate that the 1996 to 2000 period was the best time for employment growth, in terms of number of jobs, for the professional, scientific, and technical services and management of companies and enterprises sectors. Therefore, the survey that was conducted for this paper provides much needed information to the stakeholders in the region.

Identifying a region's strengths and weaknesses is a key component in retaining recent college graduates. The results of the survey provide many important insights. First, family plays a vital role in determining where a graduate ultimately locates; $43.8 \%$ of respondents remaining in the Capital District indicated this way a key factor as compared to $30.7 \%$ of those graduates who migrated. Second, and not surprisingly since graduates tend to be young

\footnotetext{
${ }^{2}$ Data obtained from the Capital District Regional Planning Commission http://www.cdrpc.org/MSA Sector Emp.html ${ }^{3}$ Ibid.
} 
and single, the survey results indicate that those respondents who migrated believe that there is a dearth of entertainment and social activities in the Capital District. In comparison, graduates that stayed in the region rated these factors slightly higher. However, in ranking the quality-of-life measures that were provided to them in the survey both groups of respondents rated entertainment and social factors almost identically. This result is very important because it signifies that either entertainment/social activities do not exist in the region or that the area is doing a poor job marketing these types of opportunities to college students. In either case stakeholders in the Capital District can address this perceived problem by college students by attracting businesses and activities to the area that would be of interest to young people, and then to market these opportunities to students in hopes of keeping them in the region after they graduate. Third, quality-of-life factors such as cost of living, educational opportunities, size of the region, and closeness to other areas were all ranked highly by the respondents to the survey. Therefore, these are key attractions to the region that policy-makers can emphasize and market to students in efforts to retain them in the region. Lastly, all the aforementioned insights will be for naught unless there are high-paying employment opportunities available for graduates, as these two factors ranked the highest for graduates staying or migrating. Moreover, as discussed in the previous paragraph, these jobs must be opportunities that graduates want. This result is not surprising, especially considering how mobile American society is today.

Despite being a center for higher education, possessing world-class cultural and historical sites, and located in an easily accessible market, young college-educated workers are leaving the Capital District. Some stakeholders will argue that the brain drain is not a major concern for the area, that the Capital District is a region perfect for people with families looking to settle down. As people age, their lifestyles change and they gain valuable work experience, making these workers highly sought after in some regions. So, should the Capital District try to stop young graduates from migrating? The brain drain of young college graduates is of prime importance to the economic development of the region because a high concentration of highly skilled college-educated workers can have many positive effects, particularly in regards productivity and the potential for economic growth. Young college graduates bring ideas and energy to a region which can lead to new businesses and economic expansion. Therefore, determining the causes of brain drain in the Capital District is an important component of the economic development of region. Future research will delve deeper into the data that was collected to determine which factors, and to what extent, increase the probability of retaining a student in the region. However, this future work should not diminish the importance of the research offered in this paper. The survey conducted and the results presented for this study provide stakeholders a detailed analysis of the types of graduates that are leaving the region, as well as a comparative investigation of the characteristics of the graduates that stay and those that leave.

\section{ACKNOWLEDGEMENTS}

The author would like to thank the Renaissance Corporation of Albany for their financial support in helping to get this project completed. The author would also like to thank the participating colleges in the study: Albany College of Pharmacy, Rensselaer Polytechnic Institute, Maria College, the Sage Colleges, Union College, Siena College, Albany Medical College, Albany Law School, Skidmore College, the College of Saint Rose, ColumbiaGreene Community College, and Fulton-Montgomery Community College. Lastly, the author would like to give a special thank you to Congressman Michael R. McNulty and his District Representative Mr. Robert E. Carr for their assistance on various parts of this project.

\section{REFERENCES}

1. Artz, G. (2003). Rural Area Brain Drain: Is it a Reality? Choices Magazine, December.

2. Barro, R.J. and Lee, J-W. (1993). International Comparisons of Educational Attainment. Journal of Monetary Economics, 32: 363-394.

3. Beine, M., Docquier, F. and Rapoport, H. (2001a). Brain Drain and Economic Growth: Theory and Evidence. Journal of Development Economics, 64: 275-89.

4. Beine, M., Docquier, F. and Rapoport, H. (2001b). Brain Drain and Growth in LDCs: Winners and Losers. Paper Presented at European Economic Association Congress, August. 
5. Bhagwati, J.N. and Hamada, K. (1974). The Brain Drain, International Integration of Markets for Professionals and Unemployment: A Theoretical Analysis. Journal of Development Economics, 1(1): 1942.

6. Bhagwati, J.N. and Hamada, K. (1975). Domestic Distortions, Imperfect Information and the Brain Drain. Journal of Development Economics, 2: 139-53.

7. Borjas, G.J., Bronars, S.G., and Trejo, S.J. (1992). Self-selection and Internal Migration in the United States. NBER Working Papers \#4002.

8. Brannon, J.I. and McGee, M.K. (2001). Draining Away: Who is Leaving the State? Where Are They Going? Wisconsin Policy Research Institute Report, 14(5).

9. Carrington, W.J. and Detragiache, E. (1998). How Big is the Brain Drain? IMF Working paper no. 201.

10. Finnie, R. (2001). The Brain Drain. Myth and Reality - What it is and What Should be Done. Kingston: School of Policy Studies, Queen's University.

11. Florida, R. (2002). The Rise of the Creative Class... and How It's Transforming Work, Leisure, Community, and Everyday Life. New York: Basic Books.

12. Florida, R. (2005). The Flight of the Creative Class: The New Global Competition for Talent. New York: Harper Books.

13. Frank, J. and Bélair, É. (1999). South of the Border. Graduates from the Class of '95 Who Moved to the United States. Ottawa: Statistics Canada.

14. Grubel, H.B. and Scott, A.D. (1966). The International Flow of Human Capital. American Economic Review, 56: 268-274.

15. Hansen, S.B., Ban, C., and Huggins, L. (2003). Explaining the "Brain Drain" from Older Industrial Cities: The Pittsburgh Region. Economic Development Quarterly, 17(2): 132-147.

16. Johnson, H.G. (1967). Some Economic Aspects of the Brain Drain. Pakistani Development Review, 7: 379411.

17. Kodrzycki, Y.K. (2001). Migration of Recent College Graduates: Evidence from the National Longitudinal Survey of Youth. New England Economic Review, Jan/Feb: 13-34.Mountford, A. (1997). Can a Brain Drain Be Good For Growth in the Source Economy? Journal of Development Economics, 53: 287-303.

20. Murray, S. (2000). Panelist Presentation. Paper presented at the Brain Drain, Brain Gain Session Proceedings, Ottawa.

21. Pennsylvania Economy League - Eastern Division. (1998). Philadelphia’s Brain Drain: Fact or Fiction. White Paper Prepared for Greater Philadelphia's Entrepreneurial Challenge Working Group, April.

22. Rodriguez, C.A. (1975). Brain Drain and Economic Growth: A Dynamic Model. Journal of Development Economics, 2(3): 223-248.

23. Salt, J. (1997). International Movements of the Highly Skilled. OECD International Migration Unit, Occasional Paper no. 3.

24. Schiffman, B. (2003). The Best Places With the Best Education. Forbes Magazine, February 14.

25. Schumpeter, J. (1942). Capitalism, Socialism, and Democracy. New York: Harper and Row.

26. Spence, M. (1974). Market Signalling. Cambridge, MA: Harvard University Press.

27. SRI International. (2002). The Economic Impact of Michigan's Public Universities. SRI Project \#: PDH 02-019.

28. Steelman, A. (2004). Why Cities Grow. Region Focus The Federal Reserve Bank of Richmond, Fall: 13-16.

29. Tornatzky, L.G., Gray, D.O., Tarant, S.A., and Zimmer, C. (2001). Who Will Stay and Who Will Leave? A Report of the Southern Technology Council, May.

30. Zhao, J., Drew, D., and Murray, T.S. (2000). Brain Drain and Brain Gain: The Migration of Knowledge Workers From and to Canada. Education Quarterly Review, 6(3): 8-35. 
NOTES 